\title{
CARYOPTERIS ODORATA: A RICH SOURCE OF ANTIOXIDANTS FOR PROTECTION AGAINST CHRONIC DISEASES AND FOOD PRODUCTS
}

\author{
TAYYABA SHAHZADI ${ }^{1}$, MUHAMMAD ATHAR ABBASI ${ }^{\prime *}$,TAUHEEDA RIAZ ${ }^{1}$, AZIZ-UR-REHMAN ${ }^{1}$, \\ SABAHAT ZAHRA SIDDIQUI ${ }^{1}$ AND MUHAMMAD AJAIB ${ }^{2}$
}

\author{
${ }^{\prime}$ Department of Chemistry, Government College University, Lahore-54000, Pakistan \\ ${ }^{2}$ Department of Botany, Government College University, Lahore-54000, Pakistan.
}

(Received: September 23, 2010 - Accepted: May 16, 2011)

\begin{abstract}
This study was designed to examine the in vitro antioxidant potential of the different fractions of Caryopteris odorata (Ham. ex Roxb.). The methanolic extract of this plant was dissolved in distilled water and partitioned with $n$-hexane, chloroform, ethyl acetate and $n$-butanol, successively. These organic fractions and the remaining aqueous fraction were screened for their possible antioxidant activities by different methods: 1,1-diphenyl-2-picrylhydrazyl radical (DPPH) scavenging activity, total antioxidant activity, ferric reducing antioxidant power (FRAP) assay and ferric thiocyanate assay. The total phenolics were also determined. The results revealed that among these fractions ethyl acetate soluble fraction showed very good antioxidant potential, having an $I C_{50} \mathrm{value} \mathrm{of} 8.01 \pm 0.254 \mu \mathrm{g} / \mathrm{mL}$. It also exhibited the highest total antioxidant activity $(2.358 \pm 0.035)$, FRAP value $(2505.8 \pm 0.58 \mu \mathrm{g} / \mathrm{mL})$, inhibition of lipid peroxidation $(77.53 \pm 0.784 \%)$ value and total phenolic contents $(87.08 \pm 1.5 \mu \mathrm{g} / \mathrm{g})$ as compared to other fractions.
\end{abstract}

Key words: Caryopteris odorata, DPPH assay, total antioxidant activity, FRAP value, total phenolics, Inhibition of lipid peroxidation (\%).

\section{INTRODUCTION}

Radicals are chemical species with one or more unpaired electrons, and free radicals are radicals that have moved out of the immediate molecular environment of their generation. There are several endogenous sources of oxidants in the body: reduction of molecular oxygen in mitochondria during cellular respiration takes place in sequential steps, yielding the radical byproducts superoxide $\mathrm{O}_{2}^{--}$, hydroxyl $\mathrm{HO}^{*}$, and hydrogen peroxide $\mathrm{H}_{2} \mathrm{O}_{2}$; degradation of fatty acids and other molecules in peroxisomes produce $\mathrm{H}_{2} \mathrm{O}_{2}$, phagocytosis results in an oxidative burst of nitric oxide ( $\mathrm{NO} \bullet$, which also reacts with superoxide to produce the oxidizing and nitrating species peroxynitrite $\left(\mathrm{ONOO}^{-}\right) .{ }^{1}$ Recent developments in biomedical science have shown that free radicals are involved in many diseases. They attack the unsaturated fatty acids in the biomembrane and result in membrane lipid peroxidation, which is strongly connected to aging, carcinogenesis and atherosclerosis. ${ }^{2-4}$ Free radicals also attack DNA and cause mutation leading to cancer. ${ }^{5}$ However, ingestion of foods containing antioxidants may reduce the oxidative damage in the human body. ${ }^{6}$ There is an increasing evidence that fruits and vegetables may protect against numerous chronic diseases, including cancer, cardio- and cerebrovascular, ocular, and neurological diseases. The protective effect of fruit and vegetables has generally been attributed to their antioxidant constituents, including vitamin $\mathrm{C}$ (ascorbic acid), vitamin $\mathrm{E}$ (a-tocopherol), carotenoids, glutathione, flavonoids and phenolic acids, as well as other unidentified compounds. Total antioxidant capacity of many fruits and vegetables has been determined by the oxygen radical absorbance capacity (ORAC) assay, which measures the ability of plant extracts to scavenge peroxyl radicals. Polyphenolic flavonoids are metabolic products widely distributed in foods of plant origin and they have numerous biological and pharmacological properties that could potentially afford protection against chronic diseases. Food-derived flavonoids have been shown to possess antioxidant, anti-inflammatory, antimutagenic and anticarcinogenic properties. ${ }^{7}$ In contrast, the synthetic forms of these compounds have been seen to have entirely different role to play with most of them possessing toxic and carcinogenic effects. ${ }^{8}$ Therefore, the potential of these phytochemical constituents for the maintenance of health and protection from coronary heart disease and cancer is also raising interest among scientists and food manufactures as consumers move towards functional foods with specific health effects. ${ }^{9}$

Caryopteris odorata (Verbenaceae) is a shrub distributed in Subtropical or outer Himalayas from Pakistan to Bhutan, India and Bangladesh. It is common in the low hills of Punjab, and has also been reported from Baluchistan. Sometimes it is also cultivated as an ornamental. ${ }^{10}$ Powdered leaves and flowers of this plant are used in diabetic foot ulcer, tumors and wounds. ${ }^{11}$ To the best of our knowledge, there has been no detailed report on the antioxidant studies of this plant, therefore, purpose of the present study was to investigate the antioxidant potential of different fractions of this plant for future investigations towards the finding of new, potent and safe antioxidant compounds.

\section{EXPERIMENTAL}

\section{Plant Material}

The plant Caryopteris odorata (Ham. ex Roxb.) having common name of path geri was collected from hills of Azad Kashmir in March 2009, and identified by Mr. Muhammad Ajaib (Taxonomist), Department of Botany, GC University, Lahore. A voucher specimen no. (G.C. Herb. Bot. 862) has been deposited in the herbarium of the same university.

Extraction and Fractionation of Antioxidants

The shade-dried ground whole plant $(7.5 \mathrm{~kg})$ was exhaustively extracted with methanol $(12 \mathrm{~L} \times 4)$ at room temperature. The extract was evaporated to yield the residue $(650 \mathrm{~g})$, which was dissolved in distilled water $(1.5 \mathrm{~L})$ and partitioned with $n$-hexane $(1 \mathrm{~L} \times 4)$, chloroform $(1 \mathrm{~L} \times 4)$, ethyl acetate $(1 \mathrm{~L}$ $\times 4)$ and $n$-butanol $(3 \mathrm{~L} \times 4)$, respectively. These fractions were concentrated separately on rotary evaporator under vacuum and the residues thus obtained were used to evaluate their in vitro antioxidant activities. The remaining aqueous fraction as well as initial crude methanolic extract was also tested for their antioxidant potential.

\section{Chemicals and Standards}

DPPH ${ }^{*}$ (1,1-Diphenyl-2-picrylhydrazyl radical), TPTZ (2,4,6-Tripyridyls-triazine), Trolox, Gallic acid, Follin Ciocalteu reagent and BHT (Butylated hydroxytoluene) were obtained from Sigma Chemical Company Ltd. (USA) and organic solvents ( $n$-hexane, chloroform, ethyl acetate, $n$-butanol), sulphuric acid, sodium phosphate, ammonium molybdate, ferric chloride and ferrous chloride from Merck (Pvt.) Ltd. (Germany).

\section{DPPH Radical Scavenging Activity}

The DPPH radical scavenging activities of various fractions of plant were examined by comparison with that of known antioxidant, butylated hydroxytoluene (BHT) using the reported method..$^{12}$ Briefly, various amounts of the samples $(400 \mu \mathrm{g} / \mathrm{mL}, 200 \mu \mathrm{g} / \mathrm{mL}, 100 \mu \mathrm{g} / \mathrm{mL}, 60 \mu \mathrm{g} / \mathrm{mL}, 50 \mu \mathrm{g} /$ $\mathrm{mL}, 30 \mu \mathrm{g} / \mathrm{mL}, 20 \mu \mathrm{g} / \mathrm{mL}, 15 \mu \mathrm{g} / \mathrm{mL}, 10 \mu \mathrm{g} / \mathrm{mL}, 8 \mu \mathrm{g} / \mathrm{mL}, 5 \mu \mathrm{g} / \mathrm{mL})$ were mixed with $3 \mathrm{ml}$ of methanolic solution of DPPH $(0.1 \mathrm{mM})$. The mixture was shaken vigorously and allowed to stand at room temperature for one an hour. Then absorbance was measured at $517 \mathrm{~nm}$ against methanol as a blank in the spectrophotometer. Lower absorbance of spectrophotometer indicated higher free radical scavenging activity.

The percent of DPPH decoloration of the samples was calculated according to the formula: Antiradical activity $=\mathrm{A}_{\text {control }}-\mathrm{A}_{\text {sample }} / \mathrm{A}_{\text {control }} \times 100$

Each sample was assayed in triplicate and mean values were calculated. 
Total Antioxidant Activity by Phosphomolybdenum Method

The total antioxidant activities of various fractions of plant were evaluated by phosphomolybdenum complex formation method. ${ }^{13}$ Briefly, $500 \mu \mathrm{g} / \mathrm{mL}$ of each sample was mixed with $4 \mathrm{~mL}$ of reagent solution $(0.6 \mathrm{M}$ sulphuric acid, $28 \mathrm{mM}$ sodium phosphate and $4 \mathrm{mM}$ ammonium molybdate) in sample vials. The blank solution contained $4 \mathrm{~mL}$ of reagent solution. The vials were capped and incubated in water bath at $95^{\circ} \mathrm{C}$ for 90 minutes. After the samples had been cooled to room temperature, the absorbance of mixture was measured at 695 $\mathrm{nm}$ against blank. The antioxidant activity was expressed relative to that of butylated hydroxytoluene (BHT). All determinations were assayed in triplicate and mean values were calculated.

\section{Ferric Reducing Antioxidant Power (FRAP) Assay}

The FRAP assay was done according to the method of Benzie and Strain ${ }^{14}$ with some modifications. The stock solutions included $300 \mathrm{mM}$ acetate buffer (3.1. $\mathrm{CH}_{3} \mathrm{COONa} .3 \mathrm{H}_{2} \mathrm{O}$ and $16 \mathrm{~mL} \mathrm{CH} \mathrm{CH}_{3} \mathrm{COOH}$ ), $\mathrm{pH} 3.6,10 \mathrm{mM}$ TPTZ (2,4,6-Tripyridyl-s-triazine) solution in $40 \mathrm{mM} \mathrm{HCl}$, and $20 \mathrm{mM} \mathrm{FeCl}_{3} \cdot 6 \mathrm{H}_{2} \mathrm{O}$ solution. The fresh working solution was prepared by mixing $25 \mathrm{~mL}$ acetate buffer, $2.5 \mathrm{~mL}$ TPTZ solution and $2.5 \mathrm{~mL} \mathrm{FeCl} .6 \mathrm{H}_{2} \mathrm{O}$ solution and then warmed at $37^{\circ} \mathrm{C}$ before using. The solutions of plant fractions and that of trolox were formed in methanol $(500 \mu \mathrm{g} / \mathrm{mL}) .10 \mu \mathrm{L}$ of each of sample solution and BHT solution were taken in separate test tubes and $2990 \mathrm{~mL}$ of FRAP solution was added in each to make total volume up to $3 \mathrm{~mL}$. The plant fractions were allowed to react with FRAP solution in the dark for 30 minutes. Readings of the coloured product [ferrous tripyridyltriazine complex] were then taken at 593 $\mathrm{nm}$. The FRAP values were determined as micromoles of trolox equivalents per $\mathrm{mL}$ of volatile oil by computing with standard calibration curve constructed for different concentrations of trolox. Results were expressed in TE $\mu \mathrm{M} / \mathrm{mL}$.

\section{Total Phenolic Contents}

Total phenolics of various fractions of plant were determined by the method of Makkar et. al. ${ }^{15}$ The $0.1 \mathrm{~mL}(0.5 \mathrm{mg} / \mathrm{mL})$ of sample was combined with $2.8 \mathrm{~mL}$ of $10 \% \mathrm{Na}_{2} \mathrm{CO}_{3}$ and $0.1 \mathrm{~mL}$ of $2 \mathrm{~N}$ Folin-Ciocalteu reagent. After 40 minutes absorbance at $725 \mathrm{~nm}$ was measured by UV-visible spectrophotometer. Total phenolics were determined as milligrams of gallic acid equivalents per gram of sample by computing with standard calibration curve constructed for different concentrations of gallic acid. The standard curve was linear between $50 \mu \mathrm{g} / \mathrm{mL}$ to $400 \mu \mathrm{g} / \mathrm{mL}$ of gallic acid. Results were expressed in $\mathrm{GAE} \mu \mathrm{g} / \mathrm{mL}$.

Ferric Thiocyanate (FTC) Assay

The antioxidant activities of various fractions of plant on inhibition of linoleic acid peroxidation were assayed by thiocyanate method. ${ }^{16}$ The $0.1 \mathrm{~mL}$ of each of sample solution $(0.5 \mathrm{mg} / \mathrm{mL})$ was mixed with $2.5 \mathrm{~mL}$ of linoleic acid emulsion $(0.02 \mathrm{M}, \mathrm{pH} 7.0)$ and $2.0 \mathrm{~mL}$ of phosphate buffer $(0.02 \mathrm{M}, \mathrm{pH}$ 7.0). The linoleic emulsion was prepared by mixing $0.28 \mathrm{~g}$ of linoleic acid, 0.28 $\mathrm{g}$ of Tween-20 as emulsifier and $50.0 \mathrm{~mL}$ of phosphate buffer. The reaction mixture was incubated for 5 days at $40^{\circ} \mathrm{C}$. The mixture without sample was used as control. The $0.1 \mathrm{~mL}$ of the mixture was taken and mixed with $5.0 \mathrm{~mL}$ of $75 \%$ ethanol, $0.1 \mathrm{~mL}$ of $30 \%$ ammonium thiocyanate and $0.1 \mathrm{~mL}$ of 20 $\mathrm{mM}$ ferrous chloride in $3.5 \% \mathrm{HCl}$ and allowed to stand at room temperature. Precisely $3 \mathrm{~min}$. after addition of ferrous chloride to the reaction mixture, absorbance was recorded at $500 \mathrm{~nm}$. The antioxidant activity was expressed as percentage inhibition of peroxidation (IP\%) $[\mathrm{IP} \%=\{1$-(abs. of sample) $/$ (abs. of control) $\} \times 100]$. The antioxidant activity of BHT was assayed for comparison as reference standard.

\section{Statistical analysis}

All the measurements were done in triplicate and statistical analysis was performed by Microsoft excel 2003. Results are presented as average \pm SEM.

\section{RESULTS AND DISCUSSION}

The 1,1-diphenyl-2-picryl hydrazyl (DPPH) radical is widely used in the model system to investigate the scavenging activities of several natural compounds such as phenolics and anthocyanins or crude mixtures such as the methanol extract of plants. DPPH is a stable free radical at room temperature and accepts an electron or hydrogen radical to form a stable diamagnetic molecule. DPPH radical is scavenged by antioxidants through the donation of a proton forming the reduced DPPH. After reduction, the color changes from purple to yellow and it can be quantified by decrease of absorbance at wavelength $517 \mathrm{~nm}$. Radical scavenging activity increased with increasing percentage of the free radical inhibition. ${ }^{17}$ The colour change from violet to yellow and fall in absorbance of the stable radical DPPH was measured for different concentrations, and the results are shown in Table 1. In our results $\%$ scavenging of DPPH by ethyl acetate soluble fraction $(92.09 \pm 0.23)$ was highest at $30 \mu \mathrm{g} / \mathrm{ml}$, while $n$-hexane soluble fraction revealed the lowest $\%$ scavenging value $(72.935 \pm 0.488)$ at $400 \mu \mathrm{g} / \mathrm{ml}$ concentration. The $I C_{50}$ value for each fraction was calculated from the curves plotted. $I C_{50}$ is the concentration of fraction causing 50 percent inhibition of absorbance and lower its value means greater antioxidant activity of the fraction. The $I C_{50}$ value of ethyl acetate soluble fraction was even lower $(8.01 \pm 0.254 \mu \mathrm{g} / \mathrm{ml})$ relative to butylated hydroxytoluene (BHT) having $I C_{50}$ value of $12.1 \pm 0.92 \mu \mathrm{g} / \mathrm{ml}$. It also showed highest antioxidant activity as compared to other fractions. The $I C_{50}$ values for other fractions decreased in order of $n$-butanol soluble fraction $>$ aqueous fraction $>$ crude methanolic extract $>$ chloroform soluble fraction $>$ $n$-hexane soluble fraction, respectively.

Table 1. Free radical scavenging activity of Caryopteris odorata (Ham. ex Roxb.) extract and fractions using 1,1-Diphenyl-2-picrylhydrazyl radical (DPPH).

\begin{tabular}{|c|c|c|c|}
\hline $\begin{array}{l}\text { S. } \\
\text { No. }\end{array}$ & Sample & $\begin{array}{c}\text { Concentration } \\
\text { in Assay } \\
(\mu \mathrm{g} / 4 \mathrm{ml})\end{array}$ & $\begin{array}{c}\text { \%age Scavenging of } \\
\text { DPPH radical } \\
\pm \text { S.E.M.M }\end{array}$ \\
\hline 1 & $\begin{array}{c}\text { Crude } \\
\text { methanolic } \\
\text { extract }\end{array}$ & $\begin{array}{c}200 \\
100 \\
50 \\
25\end{array}$ & $\begin{array}{c}89.09 \pm 0.869 \\
62.89 \pm 0.2 \\
52.1 \pm 0.82 \\
40.47 \pm 0.61\end{array}$ \\
\hline 2 & $\begin{array}{l}n \text {-Hexane } \\
\text { soluble } \\
\text { fraction }\end{array}$ & $\begin{array}{c}400 \\
200 \\
100 \\
50\end{array}$ & $\begin{array}{c}72.93 \pm 0.488 \\
64.43 \pm 0.72 \\
52.47 \pm 0.64 \\
45.89 \pm 0.742 \\
\end{array}$ \\
\hline 3 & $\begin{array}{l}\text { Chloroform } \\
\text { soluble } \\
\text { fraction }\end{array}$ & $\begin{array}{c}400 \\
200 \\
100 \\
50\end{array}$ & $\begin{array}{c}76.37 \pm 0.233 \\
62.2 \pm 0.368 \\
49.43 \pm 0.18 \\
38.89 \pm 0.742\end{array}$ \\
\hline 4 & $\begin{array}{l}\text { Ethyl } \\
\text { Acetate } \\
\text { soluble } \\
\text { fraction }\end{array}$ & $\begin{array}{c}30 \\
20 \\
10 \\
5\end{array}$ & $\begin{array}{l}92.09 \pm 0.23 \\
74.79 \pm 0.61 \\
57.28 \pm 0.12 \\
40.94 \pm 0.86\end{array}$ \\
\hline 5 & $\begin{array}{l}n \text {-Butanol } \\
\text { soluble } \\
\text { fraction }\end{array}$ & $\begin{array}{l}30 \\
20 \\
15 \\
10 \\
\end{array}$ & $\begin{array}{l}74.96 \pm 0.73 \\
61.32 \pm 0.68 \\
52.93 \pm 0.92 \\
47.73 \pm 0.93 \\
\end{array}$ \\
\hline 6 & $\begin{array}{l}\text { Aqueous } \\
\text { fraction }\end{array}$ & $\begin{array}{l}60 \\
30 \\
20 \\
10\end{array}$ & $\begin{array}{c}58.76 \pm 0.35 \\
42.96 \pm 0 \\
39.67 \pm 0 \\
37.87 \pm 1.15\end{array}$ \\
\hline 7 & $\mathrm{BHT}^{\mathrm{b})}$ & $\begin{array}{c}60 \\
30 \\
15 \\
8 \\
\end{array}$ & $\begin{array}{l}91.25 \pm 0.13 \\
75.56 \pm 0.07 \\
42.67 \pm 0.04 \\
23.57 \pm 0.31\end{array}$ \\
\hline
\end{tabular}

a) Standard mean error of three assays.

b) Standard antioxidant

Total antioxidant activity of plant fractions of Caryopteris odorata was determined by phosphomolybdenum method. This method is based on the reduction of molybdenum (VI) to molybdenum (V) by the antioxidants and the subsequent formation of a green phosphate $\mathrm{Mo}(\mathrm{V})$ complex at acidic $\mathrm{pH}$. Electron transfer occurs in this assay which depends upon the structure of the antioxidant. ${ }^{18}$ The antioxidant activities of various fractions were compared with the reference standard antioxidant BHT. The results showed that the antioxidant activity of these fractions was decreased in the following order: EtOAc soluble fraction $>n-\mathrm{BuOH}$ soluble fraction $>$ remaining aqueous fraction $>$ chloroform soluble fraction $>$ crude methanolic extract $>n$-hexane soluble fraction (Table 2).

The FRAP ferric reducing antioxidant power assay is one of the useful assays for examining the antioxidants by taking into account of their oxidationreduction potential. The FRAP assay is a convenient and reproducible assay and measures the antioxidant effect of any substance in the reaction medium as its reducing ability. The method described measures the ferric reducing ability of plasma (FRAP). At low $\mathrm{pH}$, when a ferric-tripyridyltriazine (FeIII-TPTZ) complex is reduced to the ferrous (FeII) form, an intense blue color with an absorption maximum at $593 \mathrm{~nm}$ develops. ${ }^{19,20}$ The reaction conditions favor 
reduction of the complex and, thereby, color development, provided that a reductant (antioxidant) is present. The antioxidant activity in ethyl acetate soluble fraction determined by FRAP assay was found to be significantly higher than other fractions which followed the order of $n$-butanol soluble fraction ( $2264 \pm 0.037$ $\mu \mathrm{g} / \mathrm{ml})>$ crude methanolic extract $(2051.8 \pm 0.90 \mu \mathrm{g} / \mathrm{ml})>$ chloroform soluble fraction $(1865.8 \pm 0.65 \mu \mathrm{g} / \mathrm{ml})>$ remaining aqueous fraction $(1702.5 \pm 0.15 \mu \mathrm{g} / \mathrm{ml})$ while $n$-hexane soluble fraction exhibited lowest FRAP value $(1564.5 \pm 0.31 \mu \mathrm{g} / \mathrm{ml})$.

The antioxidant activity of phenolic compounds is mainly due to their redox properties, which allow them to act as reducing agents, hydrogen donators, and singlet oxygen quenchers. In addition, they have metal-chelating potential. ${ }^{21}$ Moreover, phenolic compounds show different biological activities as antibacterial, anti-carcinogenic, anti-inflammatory, anti-viral, anti-allergic, estrogenic, and immune-stimulating agents. ${ }^{22}$ In our results, ethyl acetate soluble fraction possessed the highest amount of total phenolics compounds, having value $(87.08 \pm 1.5 \mathrm{mg} / \mathrm{g})$, followed by $n$-butanol soluble fraction $(72 \pm 1.3 \mathrm{mg} / \mathrm{g}), \mathrm{crude}$ methanolic extract $(64.5 \pm 1.6 \mathrm{mg} / \mathrm{g})$ the remaining aqueous fraction $(57.17 \pm 1.10 \mathrm{mg} / \mathrm{g})$, chloroform soluble fraction $(61.3 \pm 0.14 \mathrm{mg} / \mathrm{g}) \mathrm{while} n$-hexane soluble fraction displayed the lowest total phenolic content $(50.17 \pm 1.20 \mathrm{mg} / \mathrm{g})$ (Table 2$)$.

Table 2. $I C_{50}$, Total antioxidant activity, FRAP values, total phenolics and lipid peroxidation inhibition values of Caryopteris odorata (Ham. ex Roxb.) extract and fractions.

\begin{tabular}{|c|c|c|c|c|c|}
\hline Sample & $\begin{array}{c}\boldsymbol{I C}_{50} \text { of DPPH } \\
\text { Assay }(\mu \mathrm{g} / \mathrm{ml}) \\
\quad \pm \text { S.E.M } \\
\end{array}$ & $\begin{array}{c}\text { Total Antioxidant } \\
\text { Activity } \\
\pm \text { S.E.M }{ }^{\text {a) }}\end{array}$ & 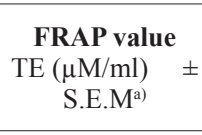 & $\begin{array}{c}\text { Total Phenolics } \\
\text { (GAE mg/g of } \\
\text { extract) } \\
\pm \text { S.E.M }{ }^{\text {a) }} \\
\end{array}$ & $\begin{array}{l}\text { Inhibition of lipid } \\
\text { peroxidation (\%) } \\
\quad \pm \text { S.E.M }{ }^{\text {a) }}\end{array}$ \\
\hline $\begin{array}{c}\text { Crude methanolic } \\
\text { extract }\end{array}$ & $52.12 \pm 0.17$ & $1.86 \pm 0.026$ & $2051.8 \pm 0.90$ & $64.5 \pm 1.6$ & $55.12 \pm 0.728$ \\
\hline $\begin{array}{l}n \text {-Hexane soluble } \\
\text { fraction }\end{array}$ & $71.61 \pm 0.27$ & $0.702 \pm 0.014$ & $1564.5 \pm 0.31$ & $50.17 \pm 1.20$ & $52.32 \pm 0.99$ \\
\hline $\begin{array}{l}\text { Chloroform soluble } \\
\text { fraction }\end{array}$ & $67.6 \pm 0.5$ & $1.877 \pm 0.0078$ & $1865.8 \pm 0.65$ & $61.3 \pm 0.14$ & $56.5 \pm 0.14$ \\
\hline $\begin{array}{l}\text { Ethyl Acetate } \\
\text { soluble fraction }\end{array}$ & $8.01 \pm 0.254$ & $2.358 \pm 0.035$ & $2505.8 \pm 0.58$ & $87.08 \pm 1.5$ & $77.53 \pm 0.784$ \\
\hline $\begin{array}{c}n \text {-Butanol soluble } \\
\text { fraction }\end{array}$ & $12.1 \pm 0.65$ & $2.092 \pm 0.08$ & $2264 \pm 0.037$ & $72 \pm 1.3$ & $67.27 \pm 0.45$ \\
\hline $\begin{array}{l}\text { Remaining Aqueous } \\
\text { fraction }\end{array}$ & $41.98 \pm 0.14$ & $1.946 \pm 0.006$ & $1702.5 \pm 0.15$ & $57.17 \pm 1.10$ & $57.81 \pm 0.785$ \\
\hline $\mathrm{BHT}^{\mathrm{b})}$ & $12.1 \pm 0.92$ & $1.2186 \pm 0.07$ & & - & $62.91 \pm 0.60$ \\
\hline
\end{tabular}

a) Standard mean error of three assays.

b) Standard antioxidant

The ferric thiocyanate method measures the amount of peroxide generated at the initial stage of linoleic acid emulsion during incubation. Here, peroxide reacts with ferrous chloride to form ferric chloride, which in turn reacts with ammonium thiocyanate to produce ferric thiocyanate, a reddish pigment. Low absorbance values measured via the FTC method indicate high antioxidant activity. ${ }^{23}$ Our results revealed that ethyl acetate soluble fraction rendered the maximum inhibition of lipid peroxidation $(77.53 \pm 0.784)$ and $n$-hexane soluble fraction displayed minimum value (52.12 \pm 0.728$)$, so the following order was observed by different fractions of this plant: ethyl acetate soluble fraction $>$ $n$-butanol soluble fraction $>$ remaining aqueous fraction $>$ chloroform soluble fraction $>$ crude methanolic extract $>n$-hexane soluble fraction. The inhibition of lipid peroxidation by BHT (standard) was $62.91 \pm 0.60$ (Table 2).

\section{CONCLUSION}

It was concluded from our study that that as the ethyl acetate soluble fraction of this plant exhibits the highest \% inhibition of DPPH radical $(92.09 \pm 0.23)$ as compared to other fractions and also the lower $I C_{50}$ value of this fraction $(8.01 \pm$ $0.254 \mu \mathrm{g} / \mathrm{ml}$ ) relative to butylated hydroxytoluene (BHT) depicted that it was a rich source for various antioxidants. This fraction also showed maximum total antioxidant activity, FRAP value, total phenolic contents and inhibition of lipid peroxidation when assayed while $n$-hexane soluble fraction showed the minimum value. It was also ascribed from the present study that further phytochemical investigations on this plant may bring new natural antioxidants into the food industry that might provide good protection against the oxidative damage which occurs both in the body and our daily foods.

\section{ACKNOWLEDGEMENT}

The authors are thankful to Higher Education Commission of Pakistan for financial grant.

\section{REFERENCES}

1. N. Krinsky, In: B. Frei (ed), Natural antioxidants in human health and disease, San Diego: Academic Press, pp.239-262, 1994.

2. R.A. Floyd, FASEB J., 4, 2587 (1990).

3. K. Yagi, Chem. Phys. Lipids., 45, 337 (1987).

4. B. Halliwell, J.M.C. Gutteridge, E.E. Gross, J. Lab. Clin. Med., 119, 598 (1992).

5. B.N. Ames, L.S. Gold, W.C. Willett, Proc. Natl. Acad. Sci. U.S.A. 92, 5258 (1995).

6. M.Y. Lin, C.L. Yen, J Agric Food Chem. 47, 1460 (1999).

7. J.O. Kuti, Food Chem., 85, 527 (2004).

8. G. Gazzani, A. Papetti, G. Massolini, M. Daglia, J. Food Chem., 6, 4112 (1998).

9. J. Javanmardi, Stushnoff, E. Locke, J.M. Vivanco, Food Chem., 83, 547 (2003).

10. S.M.H. Jafri and A. Ghfoor, In: Flora of West Pakistan, Editors: E. Nasir and S.I Ali, Verbenaceae. No.77, p. 37, 1974.

11. M. Ajaib, Z.-U.-D. Khan, N. Khan, M. Wahab, Pak. J. Bot., 42, 1407 (2010).

12. K. Lee, T. Shibamoto, Food Chem. 74, 443 (2001).

13. P. Prieto, M. Pineda, M. Aguilar, Anal. Biochem., 269, 337 (1999).

14. I.E.F. Benzie, J.J. Strain, Anal. Biochem., 239, 70 (1996).

15. H.P.S. Makkar, M. Bluemmel, N.K. Borowy, K. Becker, J. Sci. Food Agr., 61, 161(1993).

16. P. Valentao, E. Fernandes, F. Carvalho, P.B. Andrade, R.M. Seabra, M.L. Bastos, J. Agric. Food Chem. 50, 4989 (2002).

17. D.J. Huang, H.J. Chen, C.D. Lin, Y.H. Lin, Bot. Bull. Acad. Sin., 46, 99 (2008).

18. S. Miladi, M. Damak, J. Soc. Chim. Tunisie. 10, 101 (2008).

19. I.F.F. Benzie, Clin. Biochem., 29, 111 (1996). 
20. T.Z. Liu, N. Chin, M.D. Kiser, W.N. Bigler, Clin. Chem., 28, 2225 (1982).

21. C.A. Rice-Evans, N.J. Miller, P.G. Bolwell, P.M. Bramley and J.B. Pridham, Free Radical Res., 22, 375 (1995).
22. R.A. Larson, Phytochemistry, 27, 969 (1988).

23. J.S.J. Kim, M.J.Kim, J. Med. Plants Res, 4, 674, (2010). 